\title{
EFEKTIVITAS METODE PETA PIKIRAN DALAM \\ PEMBELAJARAN MENULIS TEKS BERITA \\ SISWA KELAS VIII SMPN 1 WIDASARI
}

\author{
Imas Juidah \\ e-mail: imasjuidah89@gmail.com
}

\begin{abstract}
This study aims to: (1) find out the activity of the teacher and eighth grade students of SMP Negeri 1 Widasari Indramayu in learning writing of news item text by using mind mapping, (2) know the ability profile of eighth grade students of SMP Negeri 1 Widasari in writing news item text before and after using mind mapping, (3) know the effectivity of mind mapping method toward writing news item text ability of the eighth grade students in SMP Negeri 1 Widasari. To achieve that goal, quasi-experimental research design with one group pretest-posttest is conducted. The results showed: (1) the teacher activity in learning writing of news item text by using mind mapping is in good categories with the score 82.5. Student activity in learning writing of news item text by using mind mapping is in good categories with the percentage of 53.33, (2) the students ability profile in learning writing of news item text before using the mind mapping is in sufficient category with an average score 65.2. While the profile of students ability in learning writing of news item text after using mind mapping is in good categories with an average score 83.53, (3) mind mapping method effective the ability to write news item text because $t_{\text {count }}(3.233)$ is higher than $t_{\text {table }}(1.701)$.
\end{abstract}

Keywords: Learning, Method, Mind Mapping, Learning Achievement in Writing News Item Text.

\section{PENDAHULUAN}

Menulis berarti menuangkan ide, pikiran, gagasan, pengetahuan, dan wawasan ke dalam tulisan yang sistematis dan bisa dipahami oleh orang lain. Menulis merupakan suatu kegiatan yang produktif dan ekspresif. Secara umum tujuan pembelajaran menulis adalah agar siswa dapat mengomunikasikan ide, gagasan, atau pendapat secara tertulis atau pun sebagai kegiatan mengekspresikan ilmu pengetahuan, pengalaman, hidup, ide, imaji, aspirasi dan lain-lain (Mujiyanto, dkk., 1999: 70). Salah satu keterampilan menulis yang diajarkan pada jenjang Sekolah Menengah Pertama (SMP) adalah keterampilan menulis teks berita.

Berita merupakan salah satu jenis tulisan yang isinya berupa suatu kejadian atau fakta. Penjelasan tersebut, didukung oleh Sumadiria yang menjelaskan bahwa berita adalah laporan tercepat mengenai fakta atau ide terbaru yang benar, menarik, dan atau penting bagi sebagian besar khalayak melalui media berkala seperti surat kabar, radio, televisi, media online internet (2005:65). Selanjutnya, Jauhari (2013: 193) mengemukakan bahwa berita adalah informasi yang menginformasikan peristiwa atau kejadian yang penting diketahui oleh masyarakat, yang disampaikan baik secara lisan maupun tulisan. Menulis teks berita adalah melaporkan seluk-beluk suatu peristiwa yang telah, sedang atau akan terjadi. Melaporkan berarti menulis apa yang dilihat, didengar atau dialami seseorang atau sekelompok orang. Dengan demikian, teks berita ditulis berdasarkan apa yang terjadi. Artinya, dengan menulis teks berita siswa akan menjadi tanggap dan peka terhadap kondisi dan situasi lingkungan di sekitarnya, tentunya ditunjang dengan teori-teori yang 
terkait sehingga dapat menghasilkan teks berita yang baik.

Namun, pada kenyataannnya kemampuan menulis teks berita siswa masih rendah. Hal tersebut berdasarkan data nilai menulis teks berita yang diperoleh dari guru mata pelajaran, hanya 16 siswa $(32 \%)$ dari 50 siswa yang nilai menulisnya yang sudah mencapai standar ketuntasan minimal. Rendahnya kemampuan menulis teks berita siswa juga didukung oleh Jurnal Penelitian Humaniora, Vol. 12, No. 1, Februari 2011: 74-90 oleh: Suwarti, dkk. dengan judul "Upaya Peningkatan Kemampuan Menulis Teks Berita Siswa Kelas VIII Pada SMP Negeri 1 Beringin Melalui Model Pembelajaran Kontekstual Berbasis Lingkungan." Dalam jurnal tersebut dijelaskan bahwa kemampuan siswa dalam menulis teks berita masih kurang. Hal tersebut dilihat pada nilai kemampuan awal menulis teks berita siswa dengan rerata hanya 54,68 .

Salah satu usaha yang dapat dilakukan untuk meningkatkan motivasi siswa untuk menulis teks berita dan mengembangkan daya nalarnya yaitu dengan cara menerapkan metode pembelajaran yang menarik. Metode merupakan cara pelaksanaan kegiatan dalam mencapai tujuan yaitu tujuan pembelajaran. Salah satu metode pembelajaran yang telah terbukti mampu mengoptimalkan hasil belajar adalah metode peta konsep atau disebut peta pikiran (mind mapping). Buzan (2008: 4) mengungkapkan bahwa mind mapping adalah cara mencatat yang kreatif, efektif, dan secara hafiah yang akan "memetakan" pikiran. Lebih lanjut Buzan (2004:6) mengemukakan bahwa mind map merupakan cara paling mudah untuk memasukkan informasi ke dalam otak, dan untuk mengambil informasi dari otak. Lebih lanjut Edward (2009: 64-65) mengatakan bahwa, sistem mind mapping mempunyai banyak keunggulan yang di antarnya: proses pembuatan mind mapping menyenangkan, karena tidak semata-mata hanya mengandalkan otak kiri saja dan sifatnya unik sehingga mudah diingat serta menarik perhatian mata dan otak. Berdasarkan hal tersebut, metode peta pikiran (mind mapping) ini akan sangat membantu memudahkan siswa dalam proses pembelajaran terutama digunakan dalam menulis berita.

Adapun rumusan masalah penelitian ini adalah: 1) Bagaimanakah aktivitas guru dan siswa kelas VIII SMP Negeri 1 Widasari dalam pembelajaran menulis teks berita dengan menggunakan metode peta pikiran?, 2)Bagaimanakah profil kemampuan menulis teks berita pada siswa kelas VIII SMP Negeri 1 Widasari sebelum dan sesudah menggunakan metode peta pikiran?, 3)Apakah pembelajaran menulis teks berita dengan metode peta pikiran pada siswa kelas VIII SMP Negeri 1 Widasari Kabupaten Indramayu Tahun pelajaran 2013/2014 efektif?

\section{METODE}

Penelitian ini merupakan penelitian eksperimen semu. Hal ini dilakukan karena proses randomisasi terhadap siswa yang telah dikelompokkan ke dalam kelas tertentu tidak mungkin dilakukan dengan merusak kelas yang sudah ada. Desain penelitian ini menggunakan desain penelitian one group pretest-posttest. Populasi dalam penelitian ini yaitu kemampuan siswa kelas VIII SMP Negeri 1 Widasari. Adapun, subjek penelitian ini yaitu siswa VIII-G SMPN 1 Widasari dengan jumlah 30 siswa.

Instrumen penelitian yang digunakan yaitu lembar observasi untuk guru dan siswa untuk mengetahui aktivitas yang terjadi selama proses pembelajaran dan lembar soal. Lembar soal yang diberikan adalah lembar soal menulis teks berita. Kriteria penilaian menulis teks terdiri dari kelengkapan isi berita, kelayakan berita dan kemenarikan judul. Aspek kelengkapan isi berita meliputi what, who, where, when, way, dan how. Aspek kelayakan berita terdiri dari lima kriteria, yaitu keluarbiasaan, kebaruan, kedekatan, akibat, orang penting. Aspek kemenarikan judul terdiri dari empat kriteria, yaitu spesifik, singkat \& padat, relevan, 
bahasa baku. Sedangkan teknik analisis data menggunakan uji-t. Uji-t digunakan untuk mengetahui efektivitas metode peta pikiran dalam pembelajaran menulis teks berita.

\section{HASIL DAN PEMBAHASAN}

\section{Hasil Penelitian}

Data dalam penelitian ini meliputi data skor tes awal (pre-test) dan data skor tes akhir (post-test) kemampuan menulis teks berita pada kelas eksperimen dan kelas kontrol. Data skor tes awal (pre-test) dan tes akhir (post-test) tersebut dapat dilihat dari hasil skor pada tes berupa menulis teks berita. Aspek penilaian menulis teks berita meliputi: 1) Kelengkapan isi berita; 2) Kelayakan berita; 3) Kemenarikan judul. Adapun data hasil pre-test kelas kontrol dapat dilihat pada tabel 1 berikut.

Tabel 1

Data Pre-test Kelas Kontrol

\begin{tabular}{|c|c|c|c|c|c|}
\hline \multirow[b]{2}{*}{ No } & \multirow{2}{*}{$\begin{array}{l}\text { Kode } \\
\text { Siswa }\end{array}$} & \multicolumn{3}{|c|}{ Aspek } & \multirow[b]{2}{*}{ Skor } \\
\hline & & $\begin{array}{c}\text { Kelengkapan } \\
\text { Isi Berita }\end{array}$ & $\begin{array}{c}\text { Kelayakan } \\
\text { Berita }\end{array}$ & $\begin{array}{c}\text { Kemenarikan } \\
\text { Judul }\end{array}$ & \\
\hline 1 & K.1 & 50 & 18 & 16 & 84 \\
\hline 2 & K.2 & 20 & 18 & 16 & 54 \\
\hline 3 & K.3 & 40 & 18 & 12 & 70 \\
\hline 4 & K.4 & 30 & 12 & 20 & 62 \\
\hline 5 & K.5 & 20 & 12 & 20 & 52 \\
\hline 6 & K.6 & 30 & 12 & 16 & 58 \\
\hline 7 & K.7 & 30 & 24 & 12 & 66 \\
\hline 8 & K.8 & 30 & 18 & 12 & 60 \\
\hline 9 & K.9 & 40 & 12 & 16 & 68 \\
\hline 10 & K.10 & 30 & 18 & 12 & 60 \\
\hline 11 & K.11 & 30 & 18 & 16 & 64 \\
\hline 12 & K.12 & 50 & 12 & 20 & 82 \\
\hline 13 & K.13 & 40 & 12 & 20 & 72 \\
\hline 14 & K.14 & 30 & 18 & 16 & 64 \\
\hline 15 & K.15 & 40 & 12 & 12 & 64 \\
\hline 16 & K.16 & 40 & 18 & 20 & 78 \\
\hline 17 & K.17 & 20 & 18 & 12 & 50 \\
\hline 18 & K.18 & 20 & 18 & 12 & 50 \\
\hline 19 & K.19 & 30 & 18 & 16 & 64 \\
\hline 20 & K.20 & 30 & 18 & 16 & 64 \\
\hline 21 & K.21 & 20 & 18 & 12 & 50 \\
\hline 22 & K.22 & 20 & 18 & 20 & 58 \\
\hline 23 & K.23 & 20 & 18 & 16 & 54 \\
\hline 24 & K.24 & 30 & 12 & 16 & 58 \\
\hline 25 & K. 25 & 40 & 18 & 16 & 74 \\
\hline 26 & K.26 & 40 & 24 & 12 & 76 \\
\hline 27 & К.27 & 40 & 18 & 16 & 74 \\
\hline 28 & K.28 & 30 & 18 & 16 & 64 \\
\hline
\end{tabular}




\begin{tabular}{|c|c|c|c|c|c|}
\hline \multirow{2}{*}{ No } & \multirow{2}{*}{$\begin{array}{c}\text { Kode } \\
\text { Siswa }\end{array}$} & $\begin{array}{c}|c| \\
\text { Kelengkapan } \\
\text { Isi Berita }\end{array}$ & $\begin{array}{c}\text { Kelayakan } \\
\text { Berita }\end{array}$ & $\begin{array}{c}\text { Kemenarikan } \\
\text { Judul }\end{array}$ & Skor \\
\hline 29 & K.29 & 30 & 18 & 16 & 64 \\
\hline 30 & K.30 & 40 & 18 & 20 & 78 \\
\hline \multicolumn{2}{|c|}{ Jumlah } & $\mathbf{9 6 0}$ & $\mathbf{5 0 4}$ & $\mathbf{4 7 2}$ & $\mathbf{1 9 3 6}$ \\
\hline \multicolumn{2}{|c|}{ Rerata } & $\mathbf{3 2}$ & $\mathbf{1 6 , 8}$ & $\mathbf{1 5 , 7 5}$ & $\mathbf{6 4 , 5 3}$ \\
\hline
\end{tabular}

Berdasarkan tabel data pre-test kelas kontrol tersebut, dapat diketahui bahwa kemampuan siswa pada aspek kelengkapan isi berita 32\% dengan skor tertinggi 50 dan skor terendah 20; pada aspek kelayakan berita 16,8\% dengan skor tertinggi 24 dan skor terendah 12 ; dan pada aspek kemenarikan judul $15,75 \%$ dengan skor tertinggi 20 dan skor terendah 12. Sedangkan, untuk mengetahui distribusi skor pre-test kemampuan menulis teks berita kelas kontrol dapat dilihat pada diagram 1 berikut.

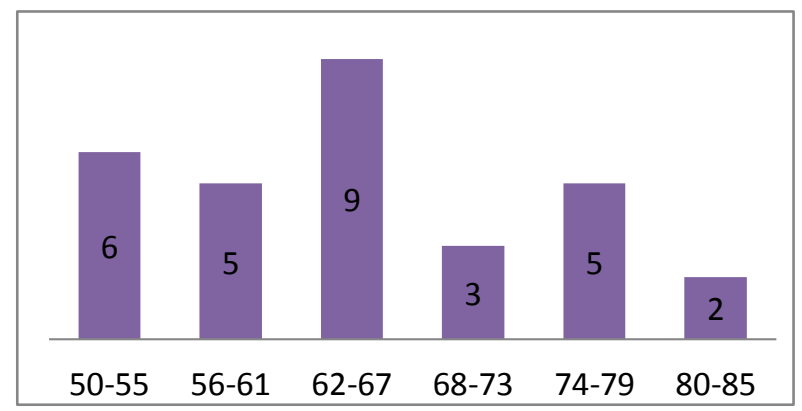

Diagram 1.

Distribusi Frekuensi Skor Pre-test Kelas Kontrol

Adapun data hasil data pre-test kelas eksperimen dapat dijelaskan pada tabel 2 berikut ini.

Tabel 2

Data Pre-test Kelas Eksperimen

\begin{tabular}{|c|c|c|c|c|c|}
\hline \multirow[b]{2}{*}{ No } & \multirow{2}{*}{$\begin{array}{l}\text { Kode } \\
\text { Siswa }\end{array}$} & \multicolumn{3}{|c|}{ Aspek } & \multirow[b]{2}{*}{ Skor } \\
\hline & & $\begin{array}{l}\text { Kelengkapan } \\
\text { Isi Berita }\end{array}$ & $\begin{array}{c}\text { Kelayakan } \\
\text { Berita }\end{array}$ & $\begin{array}{c}\text { Kemenarikan } \\
\text { Judul }\end{array}$ & \\
\hline 1 & E. 1 & 30 & 18 & 16 & 64 \\
\hline 2 & E. 2 & 40 & 12 & 16 & 68 \\
\hline 3 & E. 3 & 30 & 24 & 0 & 54 \\
\hline 4 & E. 4 & 30 & 12 & 16 & 58 \\
\hline 5 & E.5 & 40 & 18 & 12 & 70 \\
\hline 6 & E.6 & 30 & 12 & 16 & 58 \\
\hline 7 & E.7 & 40 & 18 & 12 & 70 \\
\hline 8 & E. 8 & 50 & 24 & 12 & 86 \\
\hline 9 & E.9 & 20 & 18 & 16 & 54 \\
\hline 10 & E.10 & 20 & 12 & 20 & 52 \\
\hline 11 & E.11 & 40 & 12 & 16 & 68 \\
\hline 12 & E.12 & 30 & 18 & 16 & 64 \\
\hline 13 & E.13 & 40 & 18 & 12 & 70 \\
\hline 14 & E.14 & 30 & 18 & 12 & 60 \\
\hline 15 & E.15 & 20 & 12 & 20 & 52 \\
\hline
\end{tabular}




\begin{tabular}{|c|c|c|c|c|c|}
\hline \multirow[b]{2}{*}{ No } & \multirow[b]{2}{*}{$\begin{array}{l}\text { Kode } \\
\text { Siswa }\end{array}$} & \multicolumn{3}{|c|}{ Aspek } & \multirow[b]{2}{*}{ Skor } \\
\hline & & $\begin{array}{l}\text { Kelengkapan } \\
\text { Isi Berita }\end{array}$ & $\begin{array}{c}\text { Kelayakan } \\
\text { Berita }\end{array}$ & $\begin{array}{c}\text { Kemenarikan } \\
\text { Judul }\end{array}$ & \\
\hline 16 & E.16 & 40 & 18 & 16 & 74 \\
\hline 17 & E.17 & 40 & 18 & 16 & 74 \\
\hline 18 & E.18 & 40 & 12 & 12 & 64 \\
\hline 19 & E.19 & 30 & 18 & 16 & 64 \\
\hline 20 & E.20 & 40 & 24 & 12 & 76 \\
\hline 21 & E.21 & 40 & 18 & 12 & 70 \\
\hline 22 & E.22 & 40 & 18 & 12 & 70 \\
\hline 23 & E. 23 & 40 & 18 & 12 & 70 \\
\hline 24 & E.24 & 30 & 12 & 16 & 58 \\
\hline 25 & E. 25 & 20 & 18 & 16 & 54 \\
\hline 26 & E.26 & 40 & 18 & 16 & 74 \\
\hline 27 & E.27 & 40 & 12 & 16 & 68 \\
\hline 28 & E.28 & 20 & 18 & 16 & 54 \\
\hline 29 & E.29 & 30 & 12 & 16 & 58 \\
\hline 30 & E.30 & 40 & 24 & 16 & 80 \\
\hline \multicolumn{2}{|c|}{ Jumlah } & 1020 & 504 & 432 & 1956 \\
\hline \multicolumn{2}{|c|}{ Rerata } & 34 & 16,8 & 14,4 & 65,2 \\
\hline
\end{tabular}

Berdasarkan tabel data pre-test kelas eksperimen tersebut, dapat diketahui bahwa kemampuan siswa pada aspek kelengkapan unsur berita $34 \%$ dengan skor tertinggi 50 dan skor terendah 20; pada aspek kelayakan berita $16,8 \%$ dengan skor tertinggi 24 dan skor terendah 12 ; dan pada aspek kemenarikan judul $14,4 \%$ dengan skor tertinggi 20 dan skor terendah 12. Sedangkan, untuk mengetahui distribusi skor pre-test kemampuan menulis teks berita kelas eksperimen dapat dilihat pada diagram 2 berikut.

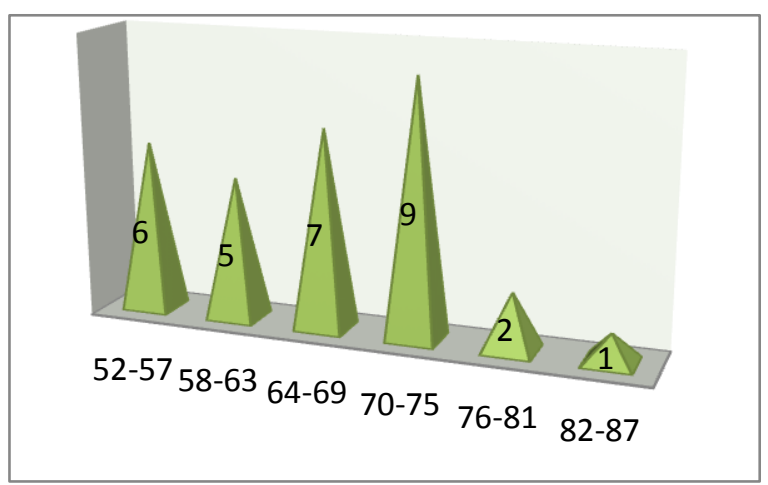

Diagram 2.

Distribusi Frekuensi Skor Pre-test Kelas Eksperimen
Perbandingan perolehan skor pre-test kelas kontrol dan kelas eksperimen tentang aspek kelengkapan isi berita, kelayakan berita, dan kemenarikan judul dapat dilihat pada diagram 3 berikut ini.

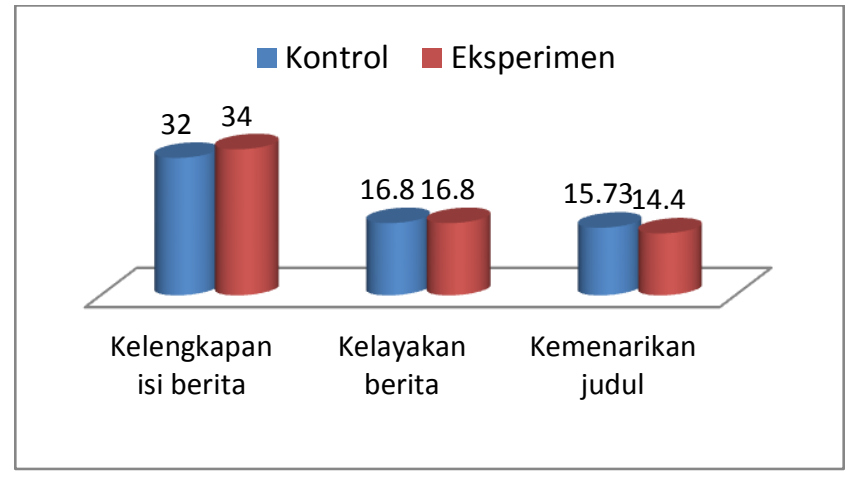

\section{Diagram 3.}

Perbandingan hasil pre-test Kelas Kontrol dan Eksperimen Berdasarkan Aspek Penilaian

Adapun data hasil post-test kelas kontrol dapat diuraikan pada tabel 3 sebagai berikut. 
Tabel 3

Data Post-test Kelas Kontrol

\begin{tabular}{|c|c|c|c|c|c|}
\hline \multirow[b]{2}{*}{ No } & \multirow{2}{*}{$\begin{array}{l}\text { Kode } \\
\text { Siswa }\end{array}$} & \multicolumn{3}{|c|}{ Aspek } & \multirow[b]{2}{*}{ Skor } \\
\hline & & $\begin{array}{l}\text { Kelengkapan } \\
\text { Isi Berita }\end{array}$ & $\begin{array}{c}\text { Kelayakan } \\
\text { Berita }\end{array}$ & $\begin{array}{c}\text { Kemenarikan } \\
\text { Judul }\end{array}$ & \\
\hline 1 & K.1 & 50 & 24 & 20 & 94 \\
\hline 2 & K.2 & 30 & 18 & 16 & 64 \\
\hline 3 & K.3 & 50 & 18 & 16 & 84 \\
\hline 4 & K.4 & 40 & 18 & 16 & 74 \\
\hline 5 & К.5 & 30 & 18 & 12 & 60 \\
\hline 6 & K.6 & 40 & 12 & 16 & 68 \\
\hline 7 & K.7 & 50 & 12 & 16 & 78 \\
\hline 8 & K. 8 & 40 & 18 & 12 & 70 \\
\hline 9 & K.9 & 50 & 18 & 20 & 88 \\
\hline 10 & K.10 & 40 & 24 & 12 & 76 \\
\hline 11 & K.11 & 40 & 12 & 20 & 72 \\
\hline 12 & K.12 & 50 & 24 & 20 & 94 \\
\hline 13 & K.13 & 40 & 24 & 20 & 84 \\
\hline 14 & K.14 & 40 & 18 & 16 & 74 \\
\hline 15 & K.15 & 40 & 24 & 16 & 80 \\
\hline 16 & K.16 & 40 & 24 & 20 & 84 \\
\hline 17 & K.17 & 30 & 18 & 12 & 60 \\
\hline 18 & K.18 & 40 & 18 & 12 & 70 \\
\hline 19 & K.19 & 40 & 18 & 12 & 70 \\
\hline 20 & K.20 & 40 & 24 & 16 & 80 \\
\hline 21 & K.21 & 30 & 18 & 12 & 60 \\
\hline 22 & K. 22 & 30 & 18 & 16 & 64 \\
\hline 23 & K.23 & 40 & 18 & 16 & 74 \\
\hline 24 & K.24 & 50 & 12 & 16 & 78 \\
\hline 25 & K. 25 & 40 & 24 & 16 & 80 \\
\hline 26 & K.26 & 40 & 24 & 16 & 80 \\
\hline 27 & К.27 & 40 & 24 & 16 & 80 \\
\hline 28 & K.28 & 40 & 18 & 16 & 74 \\
\hline 29 & K.29 & 40 & 18 & 16 & 74 \\
\hline 30 & K.30 & 50 & 18 & 20 & 88 \\
\hline \multicolumn{2}{|c|}{ Jumlah } & 1220 & 576 & 480 & 2276 \\
\hline \multicolumn{2}{|c|}{ Rerata } & 40,66 & 19,2 & 16 & 75,86 \\
\hline
\end{tabular}

Berdasarkan tabel data post-test kelas kontrol tersebut, dapat diketahui bahwa kemampuan siswa pada aspek kelengkapan unsur berita $40,66 \%$ dengan skor tertinggi 50 dan skor terendah 30; pada aspek kelayakan berita $19,2 \%$ dengan skor tertinggi 24 dan skor terendah 12; dan pada aspek kemenarikan 
judul 16\% dengan skor tertinggi 20 dan skor terendah 12 .

Sedangkan, untuk mengetahui distribusi skor post-test kemampuan menulis teks berita kelas kontrol dapat dilihat pada diagram 4 berikut.

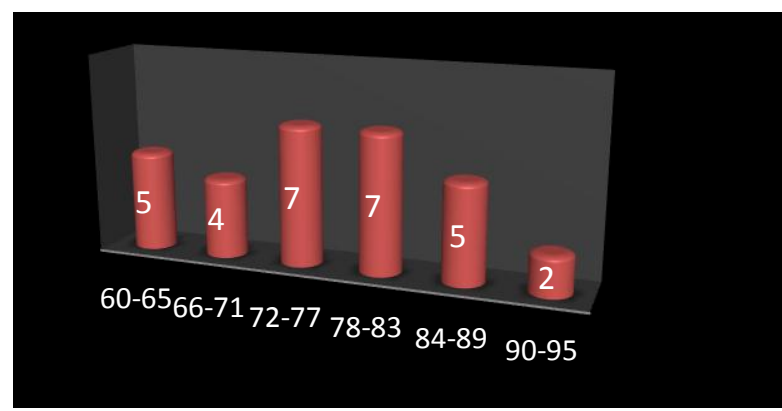

Diagram 4.

Distribusi Frekuensi Skor Post-test Kelas Kontrol

Adapun data hasil post-test kelas eksperimen dapat diuraikan pada tabel 5 berikut ini.

Tabel 5

Data Post-test Kelas Eksperimen

\begin{tabular}{|c|c|c|c|c|c|}
\hline \multirow[b]{2}{*}{ No } & \multirow{2}{*}{$\begin{array}{l}\text { Kode } \\
\text { Siswa }\end{array}$} & \multicolumn{3}{|c|}{ Aspek } & \multirow[b]{2}{*}{ Skor } \\
\hline & & $\begin{array}{l}\text { Kelengkapan } \\
\text { Isi Berita }\end{array}$ & $\begin{array}{c}\text { Kelayakan } \\
\text { Berita }\end{array}$ & $\begin{array}{c}\text { Kemenarikan } \\
\text { Judul }\end{array}$ & \\
\hline 1 & K.1 & 40 & 18 & 20 & 78 \\
\hline 2 & K.2 & 50 & 18 & 20 & 88 \\
\hline 3 & K.3 & 30 & 24 & 12 & 66 \\
\hline 4 & K.4 & 40 & 18 & 20 & 78 \\
\hline 5 & K.5 & 50 & 18 & 16 & 84 \\
\hline 6 & K.6 & 40 & 18 & 16 & 74 \\
\hline 7 & K.7 & 50 & 24 & 16 & 90 \\
\hline 8 & K.8 & 50 & 30 & 20 & 100 \\
\hline 9 & K.9 & 40 & 18 & 16 & 74 \\
\hline 10 & K.10 & 40 & 18 & 20 & 78 \\
\hline 11 & K.11 & 50 & 18 & 20 & 88 \\
\hline 12 & K.12 & 40 & 18 & 20 & 78 \\
\hline 13 & K.13 & 50 & 24 & 20 & 94 \\
\hline 14 & K.14 & 40 & 30 & 20 & 90 \\
\hline 15 & K.15 & 30 & 24 & 16 & 70 \\
\hline 16 & K.16 & 50 & 24 & 20 & 94 \\
\hline 17 & K.17 & 50 & 18 & 20 & 88 \\
\hline 18 & K.18 & 50 & 18 & 16 & 84 \\
\hline 19 & K.19 & 40 & 24 & 16 & 80 \\
\hline 20 & K.20 & 50 & 30 & 16 & 96 \\
\hline 21 & K.21 & 50 & 18 & 16 & 84 \\
\hline 22 & K. 22 & 40 & 18 & 16 & 74 \\
\hline 23 & K.23 & 40 & 24 & 16 & 80 \\
\hline 24 & K.24 & 40 & 18 & 20 & 78 \\
\hline
\end{tabular}




\begin{tabular}{|c|c|c|c|c|c|}
\hline \multirow[b]{2}{*}{ No } & \multirow{2}{*}{$\begin{array}{l}\text { Kode } \\
\text { Siswa }\end{array}$} & \multicolumn{3}{|c|}{ Aspek } & \multirow[b]{2}{*}{ Skor } \\
\hline & & $\begin{array}{l}\text { Kelengkapan } \\
\text { Isi Berita }\end{array}$ & $\begin{array}{c}\text { Kelayakan } \\
\text { Berita }\end{array}$ & $\begin{array}{c}\text { Kemenarikan } \\
\text { Judul }\end{array}$ & \\
\hline 25 & K.25 & 30 & 24 & 16 & 70 \\
\hline 26 & K.26 & 50 & 30 & 16 & 96 \\
\hline 27 & K.27 & 50 & 18 & 16 & 84 \\
\hline 28 & K.28 & 40 & 18 & 20 & 78 \\
\hline 29 & K.29 & 50 & 24 & 16 & 90 \\
\hline 30 & K.30 & 50 & 30 & 20 & 100 \\
\hline \multicolumn{2}{|c|}{ Jumlah } & 1320 & 654 & 532 & 2506 \\
\hline \multicolumn{2}{|c|}{ Rerata } & 44 & 21,8 & 17,733 & 83,53 \\
\hline
\end{tabular}

Berdasarkan tabel data pre-test kelas eksperimen tersebut, dapat diketahui bahwa kemampuan siswa pada aspek kelengkapan unsur berita $44 \%$ dengan skor tertinggi 50 dan skor terendah 20; pada aspek kelayakan berita $21,8 \%$ dengan skor tertinggi 30 dan skor terendah 12; dan pada aspek kemenarikan judul $17,73 \%$ dengan skor tertinggi 20 dan skor terendah 16.

Sedangkan, untuk mengetahui distribusi skor post-test kemampuan menulis teks berita kelas ekperimen dapat dilihat pada diagram 5 berikut.

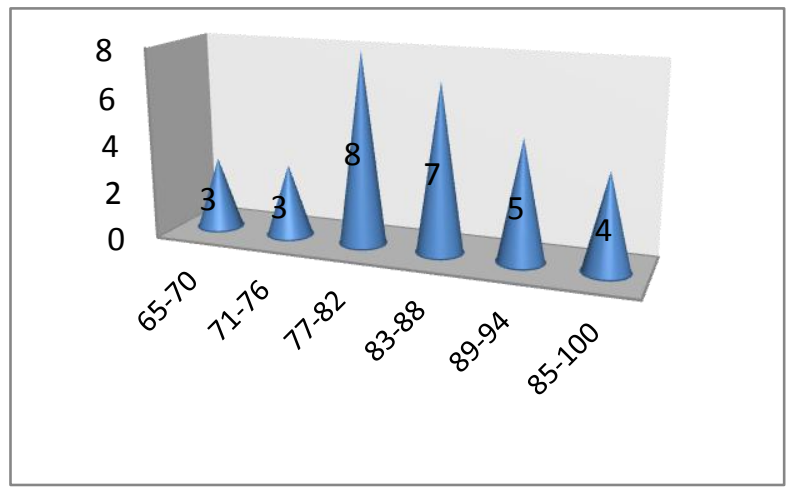

Distribusi Frekuensi Skor Post-test Kelas

Eksperimen

Perbandingan perolehan skor posttest kelas kontrol dan kelas eksperimen tentang aspek kelengkapan isi berita, kelayakan berita, dan kemenarikan judul dapat dilihat pada diagram 6 berikut ini.

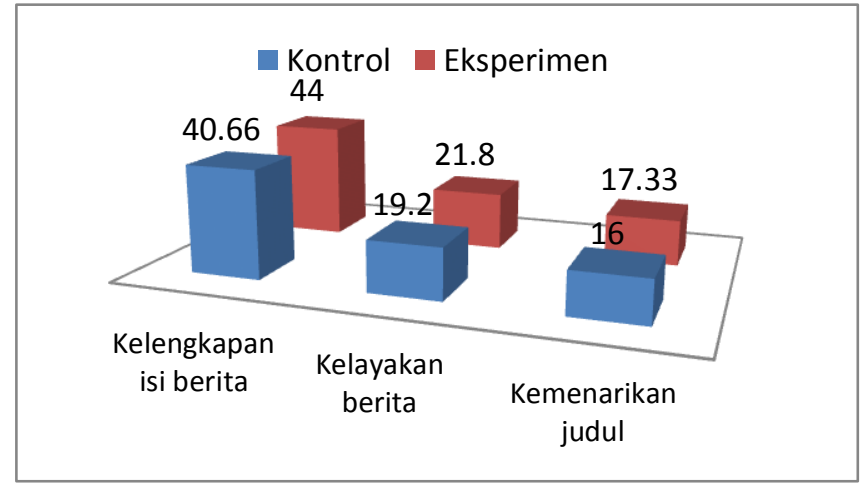

Diagram 6.

Perbandingan hasil post-test Kelas Kontrol dan Eksperimen Berdasarkan Aspek Penilaian

Kenaikan skor pre-test dan post-test kelas kontrol dan kelas eksperimen tersebut dapat dilihat pada diagram 7 berikut ini.

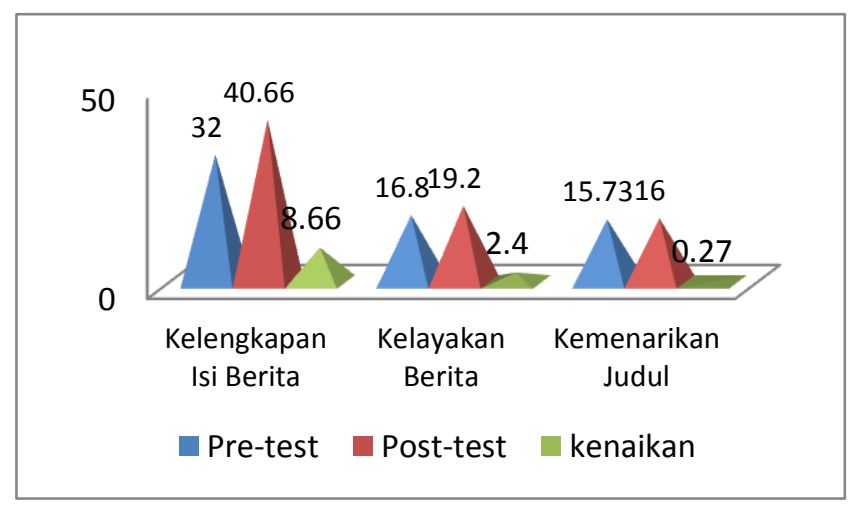

Diagram 7.

Kenaikan Skor pre-test dan Post-test Kelas Kontrol

Selanjutnya kenaikan skor pre-test dan post-test kelas ekperimen dapat dilihat pada diagram 8 berikut ini. 


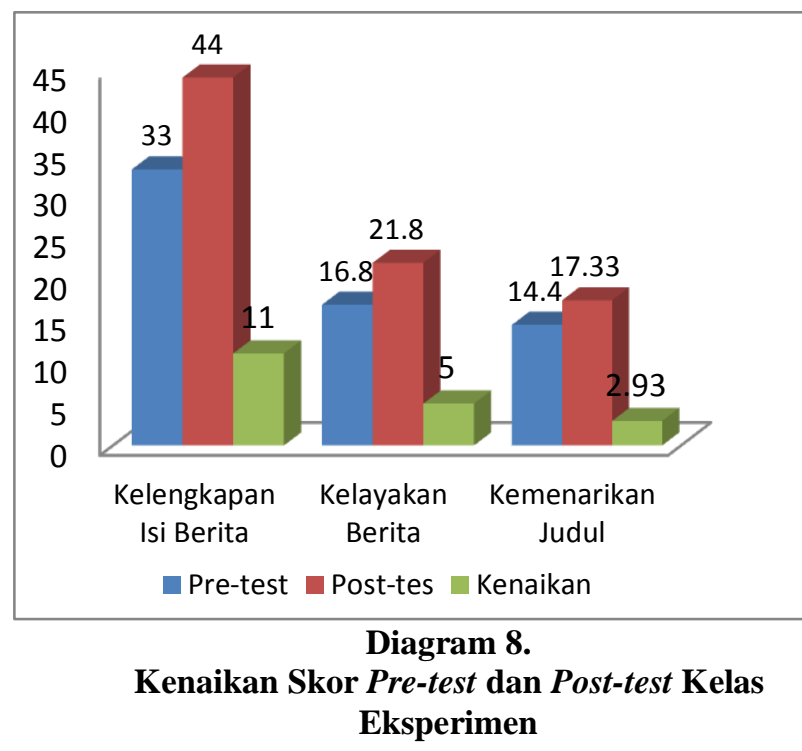

2. Pembahasan

\section{Hasil Pre-test Kelas Eksperimen}

A. Aspek Kelengkapan Isi Berita

Berdasarkan hasil analisis pre-test menulis teks berita di kelas eksperimen dengan jumlah 30 siswa yang ditinjau dari aspek kelengkapan isi berita, menunjukkan bahwa sebanyak 1 siswa $(3,33 \%)$ yang mendapat skor 50 dengan kategori sangat baik, yaitu terdiri dari 6 unsur berita (what, where, when, who, why, how). Selanjutnya, sebanyak 15 siswa (50\%) yang mendapat skor 40 dengan kategori baik, yaitu terdiri dari 5 unsur berita. Selanjutnya, sebanyak 9 siswa $(30 \%)$ mendapat skor 30 kategori cukup, yaitu terdiri dari 4 unsur berita. Sedangkan, sebanyak 5 siswa $(16,67 \%)$ mendapat skor 20 dengan kategori kurang, yaitu hanya terdiri dari 3 unsur berita. Berdasarkan hal tersebut dapat disimpulkan bahwa kemampuan siswa kelas eksperimen dalam menulis berita pada aspek pertama tergolong kategori baik karena rata-rata siswa menjawab 5 unsur kelengkapan isi berita dengan skor 40. Berikut tulisan siswa yang menjawab 5 unsur kelengkapan berita.

\section{Kecelakaan Lalu Lintas}

Kecelakaan lalu lintas mengakibatkan

7 korban mengalami luka-luka dan merusak rumah warga. Kecelakaan terjadi pada hari minggu, 9 Maret 2014 di desa Tambi Kecamatan Sliyeg Kabupaten Indramayu. Kecelakaan terjadi karena bus memaksa menyalip truk.

Awalnya bus melaju dari arah Jatibarang menuju Karangampel berupaya menyalip truk. Saat menyalip, datang sebuah mobil sedan dari arah yang berlawanan. Seketika bus bertabrakan dengan sedan, dan bus juga menabrak dua rumah warga.

Dalam teks berita siswa tersebut terdapat lima unsur kelengkapan isi berita yaitu terdapat unsur what, where, when, why, dan how. Unsur what berkenaan dengan fakta-fakta yang berkaitan dengan hal-hal yang dilakukan oleh pelaku atau pun korban dari kejadian itu. Hal yang dilakukan dapat berupa penyebab kejadian tetapi dapat pula berupa akibat kejadian. Berdasarkan penjelasan tersebut, maka unsur what dalam teks berita tersebut yaitu tentang kecelakaan lalu lintas yang mengakibatkan 7 korban mengalami luka-luka dan merusak rumah warga. Unsur what terdapat pada kalimat pertama.

Unsur where berkenaan dengan tempat peristiwa terjadi. Nama tempat kejadian harus diidentifikasi dengan jelas berikut ciri-ciri tempat kejadian. Terjadinya peristiwa kecelakaan lalu lintas yang mengakibatkan 7 korban luka-luka dan merusak rumah warga terjadi di desa Tambi Kecamatan Sliyeg Kabupaten Indramayu. Dengan demikian, unsur where dalam teks berita siswa yaitu di desa Tambi Kecamatan Sliyeg Kabupaten Indramayu. Unsur where terdapat pada kalimat kedua. Namun, dalam teks berita tersebut tidak dijelaskan ciri-ciri atau kondisi jalan di desa Sliyeg tersebut.

Unsur when berkenaan dengan waktu kejadian yang meliputi hari, tanggal, bulan, dan tahun. Selain itu perlu dicantumkan juga jam, menit bahkan detik. Berdasarkan teks berita tersebut peristiwa kecelakaan lalu 
lintas yang mengakibatkan 7 korban lukaluka dan merusak rumah warga terjadi pada hari Minggu, 9 Maret 2014. Dengan demikian, unsur when dalam teks siswa yaitu terjadi pada hari Minggu, 9 Maret 2014. Unsur when yang terdapat dalam tulisan siswa tersebut hanya terdapat hari, tanggal, bulan dan tahun terdapat pada kalimat kedua.

Unsur why berkenaan dengan faktafakta mengenai latar belakang kejadian atau penyebab dari suatu kejadian. Berdasarkan tulisan siswa tersebut penyebab peristiwa kecelakaan lalu lintas yang mengakibatkan 7 korban luka-luka dan merusak rumah warga terjadi karena bus memaksa menyalip truk. Dengan demikian unsur why dalam teks berita siswa yaitu karena bus memaksa menyalip truk. Unsur why terdapat pada kalimat ketiga.

Unsur how berkenaan dengan proses terjadinya peristiwa. Biasanya menceritakan alur kejadian bahkan diceritakan juga suasana yang terjadi pada saat peristiwa berlangsung. Peristiwa kecelakaan lalu lintas yang mengakibatkan 7 korban luka-luka dan merusak rumah warga bermula dari bus yang melaju dari arah Jatibarang menuju Karangampel berupaya menyalip truk. Saat menyalip, datang sebuah mobil sedan dari arah yang berlawanan. Seketika bus bertabrakan dengan sedan, dan bus juga menabrak dua rumah warga. Unsur how terdapat pada paragraf terakhir.

Sebuah berita yang bagus harus memiliki keenam unsur berita. Sedangkan dalam teks berita siswa tersebut hanya terdapat 5 unsur berita. Unsur yang tidak ada dalam tersebut yaitu unsur who. Dalam teks berita siswa tersebut tidak dijelaskan siapa yang menjadi korban dalam kecelakaan tersebut.

Dengan demikian, hasil tulisan siswa sebelum menggunakan metode peta pikiran, pada aspek kelengkapan isi berita rata-rata hanya menjawab 5 unsur berita saja, unsur yang jarang ada dalam tes berita siswa yaitu unsur who dan unsur how. Pada unsur what hampir seluruh siswa menuliskan peristiwa yang sama yaitu tentang peristiwa kecelakaan lalu lintas. Hal tersebut dikarenakan peristiwa kecelakaan lalu lintas merupakan peristiwa yang sering mereka lihat dan dengar baik, di televisi maupun mereka lihat langsung. Jadi, peristiwa tentang kecelakaan lalu lintas paling banyak ditulis siswa, padahal peristiwa tidak hanya tentang kecelakaan lalu lintas.

\section{B. Aspek Kelayakan Berita}

Berdasarkan hasil analisis pre-test menulis teks berita di kelas eksperimen dengan jumlah 30 siswa yang ditinjau dari aspek kelayakan berita, menunjukkan bahwa sebanyak 0 siswa $(0 \%)$ yang mendapat skor 30 dengan kategori sangat baik, yaitu terdiri dari 5 unsur kelayakan berita (mengandung nilai kebaruan, akibat, aktual, kedekatan, dan orang penting). Selanjutnya, sebanyak 4 siswa $(13,33 \%)$ yang mendapat skor 24 dengan kategori baik, yaitu terdiri dari 4 unsur kelayakan berita. Selanjutnya, sebanyak 16 siswa $(53,33 \%)$ mendapat skor 18 dengan kategori cukup, yaitu terdiri dari 3 unsur kelayakan berita. Sedangkan, sebanyak 10 siswa $(33,33 \%)$ mendapat skor 12 dengan kategori kurang, yaitu hanya terdiri dari 2 unsur kelayakan berita.

Berdasarkan hal tersebut dapat disimpulkan bahwa kemampuan siswa kelas eksperimen dalam menulis berita pada aspek kedua tergolong kategori cukup karena ratarata siswa hanya menjawab 3 unsur kelayakan berita dengan skor 18 . Berikut tulisan siswa yang menjawab 3 unsur kelayakan berita.

\section{Hilangnya Pesawat MH370}

Pesawat MH370 milik Malaysia hilang setelah lepas landas pada hari Sabtu, 8 Maret 2014. Pesawat tersebut dari Kualalumpur menuju Beijing. Namun, pada saat melintasi Samudera Hindia. Pesawat berisi 239 penumpang. 
Hilangnya pesawat MH370 Malaysia diduga karena ada pembajakan. Selaian itu, diduga juga karena ada teroris. Akibatnya, sampai sekarang pesawat belum juga ditemukan. Kemungkinan semua penumpang pesawat tewas.

Dalam teks berita siswa tersebut hanya terdapat tiga unsur kelayakan berita yaitu mengandung nilai keluarbiasaan, kebaruan, dan akibat. Berita adalah sesuatu yang luar biasa. Nilai berita peristiwa luar biasa, paling tidak dapat dilihat dari lima aspek: lokasi peristiwa, waktu peristiwa, jumlah korban, daya kejut peristiwa, dampak yang ditimbulkan baik dalam bentuk jiwa, harta, maupun perubahan aktivitas masyarakat. Berdasarkan teks siswa tersebut terdapat nilai keluarbiasaan karena peristiwa pesawat hilang merupakan suatu peristiwa yang jarang terjadi, dan nilai keluarbiasaan juga dapat dilihat dari jumlah korban yang sangat banyak yaitu sebanyak 239 orang dipastikan tewas.

Semua hal yang baru, apa pun namanya, pasti memiliki nilai berita. Berita adalah peristiwa yang baru terjadi atau yang sedang hangat dibicarakan. Kebaruan atau aktualitas terbagi dalam tiga kategori: aktualitas kalender, aktualitas waktu, aktualitas masalah. Berdasarkan hal tersebut, teks berita siswa memiliki nilai kebaruan termasuk dalam kategori aktualitas masalah kasus pesawat hilang merupakan sesuatu yang bisa dibilang baru. Baru dalam hal ini bukan berarti belum pernah terjadi pesawat hilang, tapi yang disebut memiliki nilai kebaruan atau aktualitas masalah yaitu jenis pesawat yang hilang, penyebab hilangnya pesawat, dan orang-orang yang menjadi korban dapat dikategorikan baru.

Berita adalah segala sesuatu yang berdampak luas. Apa pun yang menimbulkan akibat, maka itulah berita. Semakin besar dampak bagi masyarakat, maka semakin besar nilai kandungan beritanya.
Berdasarkan hal tersebut, teks berita yang berjudul "Hilangnya Pesawat MH370" mempunyai dampak yang besar terutama bagi perusahaan yang mengalami kerugian hingga triliunan dan sebagian besar masyarakat hilang kepercayaan terhadap pesawat Malaysia MH370. Selain itu dampak hilangnya pesawat MH370 tersebut menjadi penyebab turunnya jumlah wisatawan yang datang ke Malaysia.

Dengan demikian, sebuah berita dikatakan layak apabila mengandung lima nilai, yaitu keluarbiasaan, kebaruan, akibat, kedekatan, dan orang penting. Sedangkan, rata-rata teks berita siswa hanya terdapat tiga unsur kelayakan berita. Unsur yang jarang ada dalam tulisan berita siswa yaitu unsur orang penting. Pada teks berita siswa tidak ada yang mengungkap berita tentang orang yang terkenal atau orang penting. Siswa secara keseluruhan menulis tentang peristiwa yang sering terjadi atau yang sering mereka lihat saja. Sedangkan, berita memiliki nilai berita yang tinggi apabila mengangkat berita tentang orang yang terkenal.

\section{Aspek Kemenarikan Judul}

Berdasarkan hasil analisis pre-test menulis teks berita di kelas eksperimen dengan jumlah 30 siswa yang ditinjau dari aspek kemenarikan judul, menunjukkan bahwa sebanyak 2 siswa $(6,66 \%)$ yang mendapat skor 20 dengan kategori sangat baik, yaitu terdiri dari 4 unsur kemenarikan judul (relevan, singkat dan padat, bahasa baku, dan spesifik). Selanjutnya, sebanyak 17 siswa $(56,67 \%)$ yang mendapat skor 16 dengan kategori baik, yaitu terdiri dari 3 unsur kemenarikan judul. Selanjutnya, sebanyak 10 siswa $(33,33 \%)$ mendapat skor 12 dengan kategori cukup, yaitu terdiri dari 2 unsur kemenarikan judul. Sedangkan, sebanyak 1 siswa $(3,33 \%)$ mendapat skor 0 dengan kategori kurang, yaitu tidak terdapat judul. Berdasarkan uraian tersebut dapat disimpulkan dalam diagram berikut.

Berdasarkan hal tersebut dapat disimpulkan bahwa kemampuan siswa kelas eksperimen dalam menulis berita pada aspek 
ketiga tergolong kategori baik karena ratarata siswa menjawab 3 unsur kemenarikan judul berita dengan skor 16. Berikut tulisan siswa yang menjawab 3 unsur kemenarikan judul berita.

\section{Gunung Meletus}

Gunung Kelud yang terletak diperbatasan Kediri-Blitar, Jawa Timur, meletus sekitar pukul 22.50 WIB pada hari Jumat malam, 13 Februari 2014. Hujan abu akibat letusan gunung Kelud tersebut menimpa hingga sejumlah wilayah di Jawa Tengah dan Yogyakarta serta Wilayah lainnya. Warga yang terkena dampak hujan abu tersebut sangat membutuhkan masker, air bersih, air minum, dan makanan....

Dalam teks berita siswa tersebut terdapat tiga unsur kemenarikan judul berita yaitu terdapat unsur relevan, singkat dan padat, dan bahasa baku. Relevan artinya berkaitan atau sesuai dengan isi berita atau tidak menyimpang dari isi berita. Berdasarkan hal tersebut, berita dengan judul "Gunung Meletus" relevan dengan keseluruhan berita karena didalam teks berita tersebut berisi tentang peristiwa meletusnya Gunung Kelud.

Singkat dan padat berarti langsung menusuk jantung, tegas, lugas, terfokus, menukik pada pokok intisari berita, dan tidak bertele-tele. Secara teknis, judul berita yang baik tidak lebih dari 7 kata. Berdasarkan hal tersebut, judul teks berita siswa memiliki unsur singkat dan padat karena terdiri dari 2 kata yaitu "Gunung Meletus".

Judul adalah identitas terpenting sebuah berita. Sebagai identitas, tentu judul berita harus menggunakan bahasa baku. Teks berita siswa dengan judul "Gunung Meletus" sudah menggunakan bahasa baku.

Berdasarkan uraian tersebut, rata-rata siswa hanya menjawab tiga unsur dan unsur yang jarang ada dalam teks berita tersebut yaitu unsur spesifik. Hal tersebut dikarenakan agar pembaca tidak salah tafsir. Sedangkan, Judul berita yang di tulis siswa sebagian besar masih umum atau belum spesifik, misalnya "Gunung Meletus". Judul tersebut masih menimbulkan pertanyaan gunung apa yang meletus karena nama gunung di Indonesia sangat banyak. Seharusnya, kalau akan menulis berita tentang Gunung Kelud meletus, maka judul teks berita tersebut yaitu "Gunung Kelud Meletus Lagi”. Jadi, dengan judul yang spesifik tidak akan menimbulkan pertanyaan bagi pembaca.

Dengan demikian, hasil pre-test kelas eksperimen menunjukkan bahwa pada aspek pertama teks berita siswa masih banyak yang belum lengkap. Selain itu, teks berita masih belum diuraikan secara mendetail seperti unsur where hanya menjelaskan nama desa, kecamatan, dan kabupaten. Sedangkan, suasana disekitar lokasi kejadian tidak disampaikan. Selain itu, unsur when juga pada umumnya hanya menyebutkan bulan dan tahun. Sedangkan, berita yang baik harus menginformasikan sesuatu secara lengkap dan mendetail. Pada aspek kelayakan berita, teks berita siswa juga tidak lengkap. Sebagian besar unsur yang tidak terdapat dalam teks berita siswa yaitu unsur keluarbiasaan dan unsur orang penting jarang diperhatikan siswa. Sedangkan pada aspek ketiga yaitu aspek kemenarikan judul siswa lemah dalam unsur spesifik dan judul biasanya terlalu panjang.

\section{Hasil Post-test Kelas Eksperimen \\ A. Aspek Kelengkapan Isi Berita}

Berdasarkan hasil analisis post-test menulis teks berita di kelas eksperimen dengan jumlah 30 siswa yang ditinjau dari aspek kelengkapan isi berita, menunjukkan bahwa sebanyak 15 siswa (50\%) yang mendapat skor 50 dengan kategori sangat baik, yaitu terdiri dari 6 unsur berita (what, where, when, who, why, how). Selanjutnya, sebanyak 12 siswa (40\%) yang mendapat 
skor 40 dengan kategori baik, yaitu terdiri dari 5 unsur berita. Selanjutnya, sebanyak 3 siswa (10\%) mendapat mendapat skor 30 kategori cukup, yaitu terdiri dari 4 unsur berita. Sedangkan, sebanyak 0 siswa $(0 \%)$ mendapat skor 20 dengan kategori kurang, yaitu hanya terdiri dari 3 unsur berita. Berdasarkan diagram tersebut dapat disimpulkan bahwa kemampuan siswa kelas eksperimen dalam menulis berita pada aspek pertama tergolong kategori sangat baik karena rata-rata siswa menjawab semua unsur kelengkapan isi berita dengan skor 50 . Berikut tulisan siswa yang menjawab 6 unsur kelengkapan berita.

\section{Rombongan Pengantar Haji Tewas Tertabrak KA}

Rombongan pengantar jamaah haji di Indramayu mengalami kecelakaan di perlintasan kereta api di Kertasemaya. Peristiwa terjadi pada hari Selasa siang, 1 Oktober 2013 tepatnya pukul 10.30 WIB. Sebanyak 13 orang tewas dan 6 lainnya lukaluka. Rombongan pengantar jemaah haji yang menggunakan mobil pikap tertabrak kereta api Argo Dwipangga jurusan JakartaSolo yang sedang melintas di perlintasan kereta api di Desa Jengkok Kecamatan Kertasemaya Kabupaten Indramayu.

Tragedi kecelakaan itu terjadi saat kendaraan pikap yang ditumpangi 19 orang hendak pulang ke Desa Tegal Wirangrong Kecamatan Kertasemaya-Indramayu sehabis mengantarkan calon jamaah haji di Wisma Haji Indramayu. Namun, kecelakaan tidak bisa dihindari saat rombongan sampai diperlintasan kereta api yang tidak berpalang pintu. Awalnya, mobil pikap sempat berhenti saat ada kereta api dari arah Cirebon ke Jakarta. Begitu kereta api lewat, mobil pikap langsung menyebrang dan secara bersamaan dari arah yang berlawanan muncul kereta api Argo Dwipangga dengan kecepatan tinggi langsung menghantam mobil pikap. Akibatnya, mobil pikap terlempar hingga 52 meter dengan kondisi mobil ringsek.

Korban yang meninggal adalah Riyanti (16), Rohyatin (47), Aminah (47), Sukaesih (38),
Ismanti (4), Tanirih (24), Dea Puspita (2), Rutinih (56), Aan Anipah (12), Kunirah (48), Surijem (40), Dian (3), Udin (40). Sedangkan, korban luka adalah Sureti (45), Warsih (48), Taniah (26), Opah (22), Casmi (50), Tati (29). Kecelakaan terjadi karena diperlintasan kereta api tidak ada palang pintu dan supir mobil pikap tidak mengetahui akan ada kereta yang melintas.

Dalam teks berita siswa tersebut terdapat semua unsur kelengkapan isi berita yaitu terdapat unsur what, where, when, who, why, dan how. Unsur what berkenaan dengan fakta-fakta yang berkaitan dengan hal-hal yang dilakukan oleh pelaku atau pun korban dari kejadian itu. Hal yang dilakukan dapat berupa penyebab kejadian tetapi dapat pula berupa akibat kejadian. Berdasarkan penjelasan tersebut, maka unsur what dalam teks berita tersebut yaitu tentang kereta api menabrak mobil rombongan pengantar calon jamaah haji. Unsur what terdapat pada kalimat pertama.

Unsur where berkenaan dengan tempat peristiwa terjadi. Nama tempat kejadian harus diidentifikasi dengan jelas berikut ciriciri tempat kejadian. Terjadinya peristiwa kereta api menabrak mobil rombongan pengantar calon jamaah haji terjadi di perlintasan kereta api di Desa Jengkok, Kertasemaya-Indramayu. Dengan demikian, unsur where dalam teks berita siswa yaitu di desa Jengkok, Kertasemaya-Indramayu. Kondisi perlintasan kereta api di Desa Jengkok tersebut tidak berpalang pintu. Unsur where terdapat pada kalimat kedua.

Unsur when berkenaan dengan waktu kejadian yang meliputi hari, tanggal, bulan, dan tahun. Selain itu perlu dicantumkan juga jam, menit bahkan detik. Berdasarkan teks berita tersebut peristiwa kereta api menabrak mobil rombongan pengantar calon jamaah haji terjadi pada hari Selasa siang, 1 Oktober 2013 tepatnya pukul 11.00 WIB. Dengan demikian, unsur when dalam teks siswa yaitu terjadi pada hari Selasa siang, 1 Oktober 2013 pukul 11.00 WIB. Unsur when terdapat pada kalimat kedua. 
Unsur who berkenaan dengan fakta-fakta yang berkaitan dengan orang atau pelaku yang terlibat dalam kejadian itu, bisa juga korban dari suatu kejadian. Orang yang diberitakan harus bisa diidentifikasi namanya, umurnya, pekerjaannya, alamatnya, dan berbagai keterangan lainnya. Semakin banyak keterangan yang terkumpul mengenai orang, semakin lengkaplah berita yang disampaikan. Berdasarkan teks berita siswa tersebut,diketahui yang menjadi korban peristiwa kereta menabrak mobil rombongan pengantar calon jamaah haji berjumlah 19 orang, 13 meninggal dan 6 luka parah. Korban meninggal yaitu adalah Riyanti (16), Rohyatin (47), Aminah (47), Sukaesih (38), Ismanti (4), Tanirih (24), Dea Puspita (2), Rutinih (56), Aan Anipah (12), Kunirah (48), Surijem (40), Dian (3), Udin (40). Sedangkan, korban luka yaitu Sureti (45), Warsih (48), Taniah (26), Opah (22), Casmi (50), Tati (29). Unsur who dalam teks berita tersebut tidak diberitakan secara lengkap, hanya terdapat nama dan umur saja. Unsur why berkenaan dengan fakta-fakta mengenai latar belakang kejadian atau penyebab dari suatu kejadian. Berdasarkan tulisan siswa tersebut penyebab dari peristiwa kereta api menabrak mobil rombongan pengantar calon jamaah haji karena tidak ada palang pintu yang memberi aba-aba akan ada kereta lewat, dan juga supir mobil pikap tidak mengetahui bahwa akan ada kereta yang melintas. Dengan demikian unsur why dalam teks berita siswa yaitu karena ketidaktahuan supir mobil pikap kalau akan ada kereta yang lewat dan karena tidak ada palang pintu. Unsur why terdapat pada kalimat ketiga.

Unsur how berkenaan dengan proses terjadinya peristiwa dari awal sampai akhir. Biasanya menceritakan alur kejadian bahkan diceritakan juga suasana yang terjadi pada saat peristiwa berlangsung. Peristiwa kereta api menabrak mobil rombongan pengantar calon jamaah haji bermula saat mobil pikap yang ditumpangi 19 orang hendak pulang ke Desa Tegal Wirangrong sehabis mengantar salah satu calon jamaah haji di Wisma
Indramayu. Pada saat sampai diperlintasan mobil pikap sempat berhenti karena tahu akan ada kereta yang lewat. Setelah kereta dari arah Cirebon-Jakarta lewat, mobil pikap langsung melintasi rel kereta api. Namun, tak disangka dari arah yang berlawanan muncul kereta api Argo Dwipangga jurusan JakartaSolo dengan kecepatan tinggi. Tabrakan pun tidak bisa dihindari. Mobil pikap terlempar hingga 52 meter dengan kondisi mobil ringsek. Unsur how terdapat pada paragraf kedua.

Dengan demikian, hasil tulisan siswa sesudah menggunakan metode peta pikiran, pada aspek kelengkapan isi berita rata-rata tulisan siswa sudah lengkap yaitu terdapat semua unsur berita $(5 \mathrm{~W}+1 \mathrm{H})$. Namun, masih belum sempurna karena walaupun sudah lengkap tetapi tidak begitu mendetail. Pada unsur what masih terdapat beberapa siswa yang menuliskan peristiwa tentang kecelakaan lalu lintas. Hal tersebut dikarenakan peristiwa kecelakaan lalu lintas merupakan peristiwa yang sering mereka lihat dan dengar baik, di televisi maupun mereka lihat langsung. Namun, banyak juga yang mengambil peristiwa lain seperti peristiwa tentang kebajiran, gunung meletus, dan kebakaran. Jadi, peristiwa yang ditulis siswa sudah mulai beragam, tidak hanya menuliskan peristiwa yang sering mereka lihat tetapi terdapat juga siswa yang tertarik dengan peristiwa yang baru atau yang sedang hangat terjadi. Pada unsur who tulisan siswa sudah mengalami peningkatan karena tidak hanya menyebutkan nama tetapi juga sudah mencantumkan umurnya. Begitu juga pada unsur when, siswa sudah jeli dan tidak hanya menyebutkan tanggal, bulan, dan tahun saja, melainkan jam dan menit juga dicantumkan.

\section{B. Aspek Kelayakan Berita}

Berdasarkan hasil analisis post-test menulis teks berita di kelas eksperimen dengan jumlah 30 siswa yang ditinjau dari aspek kelayakan berita, menunjukkan bahwa sebanyak 5 siswa (17\%) yang mendapat skor 30 dengan kategori sangat baik, yaitu terdiri dari 5 unsur kelayakan berita (mengandung 
nilai keluarbiasaan, kebaruan, kedekatan, akibat, dan orang penting). Selanjutnya, sebanyak 9 siswa (30\%) yang mendapat skor 24 dengan kategori baik, yaitu terdiri dari 4 unsur kelayakan berita. Selanjutnya, sebanyak 16 siswa $(53,33 \%)$ mendapat skor 18 dengan kategori cukup, yaitu terdiri dari 3 unsur kelayakan berita. Sedangkan, sebanyak 0 siswa (0\%) mendapat skor 12 dengan kategori kurang, yaitu hanya terdiri dari 2 unsur kelayakan berita.

Berdasarkan uraian tersebut dapat disimpulkan bahwa kemampuan siswa kelas eksperimen dalam menulis berita pada aspek kedua tergolong kategori cukup karena ratarata siswa hanya menjawab 3 unsur kelayakan berita dengan skor 18. Berikut tulisan contoh siswa yang terdapat semua unsur kelayakan berita dengan kategori sangat baik.

\section{Mobil Dul Menabrak Daihatsu dan Avanza}

Tabrakan terjadi di kilometer 8 Tol Jagorawi, Jakarta Timur arah Cibubur, pada hari minggu 8 September 2013 sekitar pukul 00.45 WIB dini hari. AQJ alias Dul anak musisi Ahmad Dani kehilangan kendali pada saat mengendarai mobil Mitsubishi. Mobil Dul menabrak pembatas jalan dan masuk ke jalur yang berlawanan. Tidak berhenti samapi disitu mobil Dul juga menabrak mobil Daihatsu yang ditumpangi 13 orang dan mobil Avanza yang ditumpangi 2 orang. Akibatnya 4 orang tewas di tempat, sementara 2 orang lainnya meninggal ketika dilarikan ke rumah sakit dan sembilan lainnya luka berat, termasuk Dul.

Dalam teks berita siswa tersebut terdapat semua unsur kelayakan berita yaitu mengandung nilai keluarbiasaan, kebaruan, akibat, dan kedekatan. Berita adalah sesuatu yang luar biasa. Nilai berita peristiwa luar biasa, paling tidak dapat dilihat dari lima aspek: lokasi peristiwa, waktu peristiwa, jumlah korban, daya kejut peristiwa, dampak yang ditimbulkan baik dalam bentuk jiwa, harta, maupun perubahan aktivitas masyarakat. Berdasarkan teks siswa tersebut terdapat nilai keluarbiasaan kalau dilihat dari aspek jumlah korban dan akibat yang ditimbulkan. Hal tersebut dikarenakan jumlah korban akibat dari kecelakaan itu sebanyak 15 korban, 6 orang tewas dan 9 lainnya luka berat.

Semua hal yang baru, apa pun namanya, pasti memiliki nilai berita. Berita adalah peristiwa yang baru terjadi atau yang sedang hangat dibicarakan. Kebaruan atau aktualitas terbagi dalam tiga kategori: aktualitas kalender, aktualitas waktu, aktualitas masalah. Berdasarkan hal tersebut, teks berita siswa memiliki nilai kebaruan termasuk dalam kategori aktualitas masalah. Peristiwa kecelakaan bukanlah sesuatu yang baru karena hal tersebut sudah sering terjadi, yang disebut baru dalam hal ini yaitu penyebab terjadinya kecelakaan dan orangorang yang menjadi korban dalam kecelakaan tersebut yaitu termasuk dalam kategori baru.

Berita adalah segala sesuatu yang berdampak luas. Apa pun yang menimbulkan akibat, maka itulah berita. Semakin besar dampak bagi masyarakat, maka semakin besar nilai kandungan beritanya. Berdasarkan hal tersebut, teks berita yang berjudul "Mobil Dul Menabrak Daihatsu dan Avanza" mempunyai dampak yang besar terutama bagi korban dan keluarganya.

Berita adalah kedekatan. Kedekatan mengandung dua arti yaitu kedekatan geografis dan kedekatan psikologis. Kedekatan geografis menunjuk pada sudatu peristiwa yang terjadi di sekitar tempat tinggal kita. Sedangkan, kedekatan psikologis lebih banyak ditentukan oleh tingkat keterikatan pikiran, perasaan, atau kejiwaan seseorang dengan suatu peristiwa. Berdasarkan hal tersebut, teks berita siswa yang berjudul "Mobil Dul Menabrak Mobil Daihatsu dan Avanza" memiliki nilai kedekatan yaitu dekat secara geografis. Hal tersebut, dikarenakan peristiwa terjadi masih di wilayah Indonesia. Jadi, teks berita siswa tersebut memiliki nilai kedekatan. 
Berita adalah tentang orang-orang penting, orang-orang ternama, tersohor, selebritis, dan publik figur. Orang-orang penting, orangorang terkemuka, di mana pun selalu menarik untuk dijadikan berita. Berdasarkan hal tersebut, teks berita siswa tersebut memiliki unsur orang penting karena tersangka dari kecelakaan tersebut seorang seleberitis yaitu "Dul".

Dengan demikian, hasil tulisan siswa sesudah menggunakan metode peta pikiran, pada aspek kelayakan berita rata-rata tulisan siswa mengalami sedikit peningkatan, karena terdapat lima siswa yang memiliki semua unsur-unsur kelayakan berita yaitu mengandung nilai keluarbiasaan, kedekatan, kebaruan, akibat dan orang penting. Terdapat lima siswa yang menulis teks berita tentang peristiwa yang dialami oleh orang terkenal atau selebritis, diantaranya yaitu peristiwa kecelakaan Uje, kecelakaan Dul, kecelakaan Adi Firansyah, dan kecelakaan yang dialami Richard Kevin. Berita-berita tentang orang terkenal tersebut memiliki nilai berita yang tinggi karena berita tentang selebritis selalu mempunyai daya tarik tersendiri bagi penggemarnya. Berita tersebut dikatakan menarik bagi siswa apabila peristiwa tersebut dialami oleh idolanya.

\section{Aspek Kemenarikan Judul}

Berdasarkan hasil analisis post-test menulis teks berita di kelas eksperimen dengan jumlah 30 siswa yang ditinjau dari aspek kemenarikan judul, menunjukkan bahwa sebanyak 14 siswa $(46,67 \%)$ yang mendapat skor 20 dengan kategori sangat baik, yaitu terdiri dari 4 unsur kemenarikan judul (relevan, singkat dan padat, bahasa baku, spesifik). Selanjutnya, sebanyak 15 siswa $(50 \%)$ yang mendapat skor 16 dengan kategori baik, yaitu terdiri dari 3 unsur kemenarikan judul. Selanjutnya, sebanyak 1 siswa $(3,33 \%)$ mendapat skor 12 dengan kategori cukup, yaitu terdiri dari 2 unsur kemenarikan judul. Sedangkan, sebanyak 0 siswa (0\%) mendapat skor 8 dengan kategori kurang, yaitu hanya terdapat satu unsur.
Berdasarkan uraian tersebut dapat disimpulkan bahwa kemampuan siswa kelas eksperimen dalam menulis berita pada aspek ketiga tergolong kategori sangat baik karena rata-rata siswa menjawab 4 unsur kemenarikan judul berita dengan skor 20 . Berikut tulisan siswa yang termasuk kategori sangat baik karena terdapat semua unsur kemenarikan judul berita.

\section{Bus Lorena Tabrak Angkot Anak SMP}

Pada hari Selasa, 30 April 2013 sekitar pukul 07.00 WIB terjadi kecelakaan maut yang melibatkan bus Lorena dengan angkutan kota terjadi di simpang jalur pantura, desa Bangkaloa, Kecamatan Widasari Kabupaten Indramayu. Kecelakaan tersebut merenggut nyawa sopir angkot, Didi Suhedi (30), warga Desa Rancajawat, Kecamatan TukdanaIndramayu karena tergencet mobil bus.

Selain itu, 14 siswa mengalami luka-luka, empat diantaranya kritis dan dilarikan ke Rumah Sakit Mitra Plumbon Cirebon. Korban luka lainnya dibawa ke Rumah Sakit Zamzam Jatibarang. Umumnya korban yang sebagian besar siswa SMPN 1 Widasari itu mengalami luka patah tulang.

Kecelakaan bermula saat angkot melaju kencang dari arah Indramayu hendak menyebrang ke Bangkaloa. Angkot tersebut menyerobot untuk menyebrang padahal angkot dan kendaraan lain sedang berhenti di tengah jalan. Pada saat menyebrang, angkot langsung disambar oleh bus Lorena yang sedang melaju kencang dari arah Cirebon menuju Jakarta.

Dalam teks berita siswa tersebut terdapat semua unsur kemenarikan judul berita yaitu terdapat unsur relevan, singkat dan padat, bahasa baku dan spesifik. Relevan artinya berkaitan atau sesuai dengan isi berita atau tidak menyimpang dari isi berita. Berdasarkan hal tersebut, berita dengan judul "Bus Lorena Tabrak Angkot Anak SMP" relevan dengan keseluruhan berita karena didalam teks berita tersebut berisi tentang peristiwa kecelakaan maut yang melibatkan 
bus Lorena dengan angkutan kota yang membawa ana-anak SMP N 1 Widasari.

Singkat dan padat berarti langsung menusuk jantung, tegas, lugas, terfokus, menukik pada pokok intisari berita, dan tidak bertele-tele. Secara teknis, judul berita yang baik tidak lebih dari 7 kata. Berdasarkan hal tersebut, judul teks berita siswa memiliki unsur singkat dan padat karena tidak lebih dari 7 kata yaitu "Bus Lorena Tabrak Angkot Anak SMP”.

Judul adalah identitas terpenting sebuah berita. Sebagai identitas, tentu judul berita harus menggunakan bahasa baku. Teks berita siswa dengan judul "Bus Lorena Tabrak Angkot Anak SMP” sudah menggunakan bahasa baku.

Spesifik berarti judul berita tidak saja harus mewakili dan mencerminkan isi berita, tetapi sekaligus juga harus mengandung kata-kata khusus. Spesifik berarti pula judul berita jangan menggunakan kata-kata umum. Teks berita siswa dengan judul "Bus Lorena Tabrak Anak SMP" sudah menggunakan kata-kata khusus sebagai judul. Di dalam judul sudah disebutkan yang bus menabrak angkot anak SMP itu bus Lorena.

Dengan demikian, hasil post-test menunjukkan adanya peningkatan disetiap aspeknya. Pada aspek pertama teks berita siswa sudah dikatakan sangat baik karena memiliki semua unsur kelengkapan berita. Pada unsur what sudah mulai beragam, tidak hanya menuliskan peristiwa tentang kecelakaan lalu lintas saja. Selain itu, teks berita siswa sudah mulai lebih mendetail seperti dalam unsur when tidak hanya menyebutkan unsur hari, tanggal, bulan, dan tahun saja melainkan mencantumkan juga jam dan menit terjadinya peristiwa. Dengan demikian, menulis teks berita siswa menjadi lebih baik atau mengalami peningkatan. Begitu juga pada aspek kedua yaitu kelakayan berita, beberapa siswa menulis berita tentang orang ternama atau selebriti yang jarang ditulis oleh siswa lain dan aspek ketiga yaitu kemenarikan judul juga mengalami peningkatan.
Jika dilihat berdasarkan perolehan skor pre-test dan post-test, data peningkatan hasil belajar kelas eksperimen dapat dilihat pada diagram 9 berikut ini.

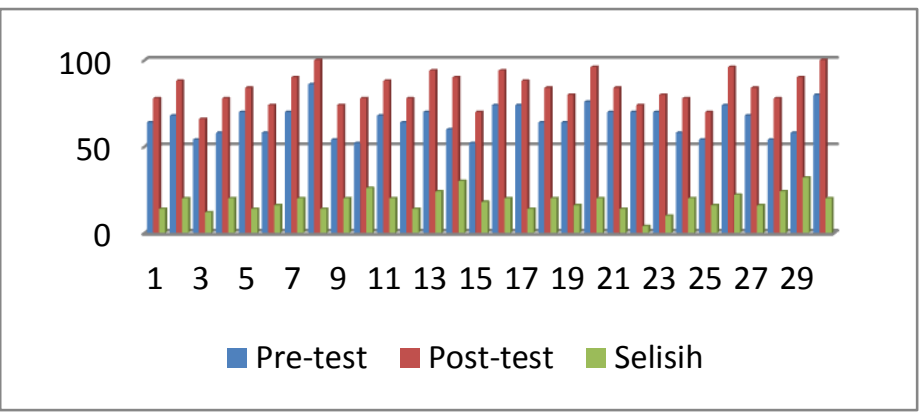

Diagram 9.

peningkatan hasil belajar kelas eksperimen

Berdasarkan diagram 9 tersebut, dapat disimpulkan bahwa kemampuan menulis teks berita siswa meningkat secara signifikan setelah pembelajaran menggunakan metode peta pikiran.

\section{SIMPULAN}

Berdasarkan hasil dan pembahasan tersebut, dapat disimpulkan sebagai berikut.

1. Aktivitas guru dalam pembelajaran menulis teks berita dengan menggunakan metode peta pikiran termasuk dalam kategori baik. Hal ini dibuktikan dari hasil observasi guru diperoleh skor 66 dengan nilai 82,5. Sedangkan, aktivitas siswa dalam pembelajaran menulis teks berita dengan menggunakan metode peta pikiran termasuk dalam kategori baik. Hal ini dibuktikan dari hasil observasi siswa dalam kelas eksperimen sebanyak 16 siswa atau 53,33\% siswa yang mengikuti pembelajaran dengan baik.

2. Profil kemampuan siswa dalam pembelajaran menulis teks berita sebelum menggunakan metode peta pikiran termasuk dalam kategori cukup. Hal ini dibuktikan dengan nilai rerata siswa sebesar 65,2. Sedangkan profil kemampuan siswa dalam pembelajaran menulis teks berita sesudah menggunakan metode peta pikiran termasuk kategori baik. Hal ini 
dibuktikan dengan nilai rerata siswa sebesar 83,53.

3. Pembelajaran menulis teks berita dengan metode peta pikiran pada siswa kelas VIII SMP Negeri 1 Widasari Kabupaten Indramayu Tahun Pelajaran 2013/2014 fektif. Hal ini dibuktikan dengan nilai $t_{\text {hitung }}(3,233)$ lebih besar dari $t_{\text {tabel }}(1,701)$ maka Ho ditolak, artinya pembelajaran menulis teks berita dengan menggunakan metode peta pikiran terbukti efektif.

\section{DAFTAR PUSTAKA}

Arikunto, Suharsimi. 2010. Prosedur Penelitian Suatu Pendekatan Praktik. Jakarta: Rineka Cipta.

Buzan, Tony. 2008. Buku Pintar Mind Map. Jakarta : PT. Gramedia Pustaka Utama.

Buzan. Tony. 2004. Mind Mapp untuk Meningkatkan Kreativitas. Jakarta: PT. Gramedia Pustaka Utama.
Edward, Caroline. 2009. Mind Mapping untuk anak sehat dan cerdas. Sakti: Yogyakarta.

Jauhari, Heri. 2013. Terampil mengarang: dari Persiapan Hingga Presentasi, dari Karangan Ilmiah Hingga Sastra. Bandung: Nuansa Cendekia.

Mujiyanto, Yant.,dkk. 1999. Puspa Ragam Bahasa Indonesia. Surakarta: Depdikbud Universitas Sebelas Maret.

Sumadiria, AS Haris. 2005. Jurnalistik Indonesia: Menulis Berita dan Feature Panduan Praktis Jurnalis Profesional. Bandung: Rosdakarya.

Suwarti, dkk. 2011. "Upaya Peningkatan Kemampuan Menulis Teks Berita Siswa Kelas VIII pada SMP Negeri 1 beringin Melalui Model Pembelajaran Kontekstual Berbasis Lingkuangan". Jurnal Penelitian Humaniora, Vol. 12, No. 1, Pebruari 2011: 74-90. 